\title{
ANALISIS DAYA SAING USAHATANI KOPI LIBERIKA DI KABUPATEN KEPULAUAN MERANTI PROVINSI RIAU DENGAN PENDEKATAN POLICY ANALYSIS MATRIX (PAM)
}

\author{
Nur Azizah ${ }^{1}$, Elinur $^{2}$, Novia Dewi ${ }^{3}$ \\ nurazizah_1289@yahoo.com
}

Program Studi Magister Agribisnis, Fakultas Pertanian, Universitas Riau, Jln.Binawidya 30, Pekanbaru, 28293, Indonesia

1* Mahasiswa Magister Agribisnis, Fakultas Pertanian, Universitas Riau 2* Dosen Agribisnis, Fakultas Pertanian, Universitas Riau

\begin{abstract}
ABSTRAK
Kopi merupakan salah satu komoditas unggulan dan penting bagi Kabupaten Kepulauan Meranti. Di Kabupaten Kepulauan Meranti, kopi merupakan komoditas yang menjadisalah satu komoditas unggulan daerah. Saat ini isu startegi daerah yang tertuangdalam RPJM Kabupaten Kepulauan Meranti 2016 -2021 adalah peningkatan daya saingproduk pertanian.Penulisan ini bertujuan untuk 1) Menganalisis keunggulan kompetitif usahatanikopi liberika di Kabupaten Kepulauan Meranti, 2) Menganalisis keunggulan komperatifusahatani kopi liberika di Kabupaten Kepulauan Meranti, 3) Menganalisis dampakkebijakan pemerintah terhadap daya saing kopi liberika di Kabupaten Kepulauan Merantidan 4)Menganalisis sensitivitas daya saing kopi liberika terhadap perubahan input output. Penelitian ini dilakukan dengan metode Stratified random sampling dengan jumlah sampel54 responden. Penentuan daerah penulisan dilakukan dengan sengaja (purposive).

Hasil analisis dengan menggunakan metode Policy Analiysis Matrix (PAM) didapatkan bahwa usahatani kopi liberika di Kabupaten Kepulauan Meranti memiliki dayasaing yang tinggi, (keunggulan kompetitif dan keunggulan komperatif) hal inidiketahui dengan nilai PCR dan DRCR yang kecil dari satu yaitu sebesar 0,39 dan0,07. Untuk kebijakan pemerintah terhadap output. Untuk nilai Transfer factor positif 11.950 menunjukkan adanya kebijakan pemerintah terhadap inputdomestik berupa pajak. Untuk kebijakan input - output belum berjalan secara efektifatau kebijakan pemerintah saat ini kurang mendukung atau melindungi petani kopi diKabupaten Kepulauan Meranti. Kebijakan pemerintah ini terjadi pada perdagangan kopisehingga petani kopi belum dapat menerima harga kopi seperti harga sosial, hal ini disebabkan rantai pemasaran kopi yang harus di lalui petani.Hasil analisis sensitivitas menunjukan bahwa usaha tani kopi liberika tetapmempunyai daya saing yang baik (keunggulan kompetitif dan komparatif) walaupunterjadi perubahan input dan output dengan asumsi faktor lainnya tetap (ceterisparibus) yang terlihat dengan nilai PCR dan DRCR tetap di bawah 1 .
\end{abstract}

Kata Kunci : Daya saing, Policy Analysis Matrix, PAM

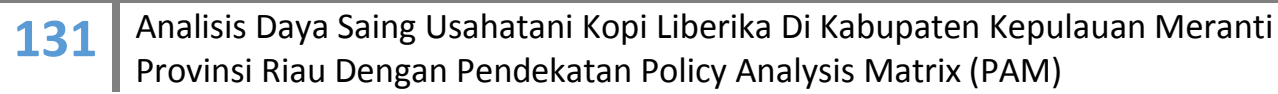




\section{PENDAHULUAN}

Kopi merupakan komoditi perkebunan yang masuk dalam kategori komoditi strategis di Indonesia. Secara formal perkebunan adalah usahatani yang mengusahakan tanaman perkebunan yang luasnya lebih dari $25 \mathrm{Ha}$.Salah satu tanaman keras perkebunan adalah tanaman kopi. Kopi adalah suatu jenis tanaman tropis yang dapat tumbuh dimana saja, terkecuali pada tempat-tempat yang terlalu tinggi dengan temperatur yang sangat tinggi atau daerah-daerah tandus yang memang tidak cocok bagi kehidupan tanaman. Sudah beberapa abad lamanya tanaman kopi menjadi bahan perdagangan karena kopi dapat diolah menjadi minuman yang lezat rasanya. Dengan kata lain kopi adalah sebagai penyegar badan dan pikiran. Badan yang lemah dan rasa kantuk dapat hilang setelah minum kopi panas, terlebih orang yang sudah menjadi pencandu kopi, bila tidak minum kopi rasanya akan capai dan tidak dapat berpikir dengan baik (AAK, 1988 dalam Simaibang. 2008)

Berdasarkan data Dinas Perkebunan Provinsi Riau tahun 2015, secara umum perkembangan luas areal kopi di Indonesia pada periode tahun 2010-2015 cenderung mengalami peningkatan yaitu dari 1.238.476 ha tahun 2010 menjadi 1.254.382 ha di tahun 2015. Begitu pula dengan produksi perkebunan kopi di Indonesia dari tahun 2010-2015 telah mengalami peningkatan. Pada tahun 2010 produksi kopi di Indonesia mencapai 634.076 ton dan pada tahun 2015 jumlah produksi kopi menjadi 739.005 ton.

Di Kabupaten Kepulauan Meranti, kopi merupakan komoditas yang menjadi salah satu komoditas unggulan daerah. Saat ini isu startegi daerah yang tertuang dalam Rencana Pembangunan Jangka Menengah (RPJM) Kabupaten Kepulauan Meranti 2016-2021 adalah peningkatan daya saing produk pertanian. Sebagai salah satu komoditas pertanian yang menjadi komuditas unggulan di Kabupaten Kepulauan Meranti, usahatani kopi liberika sejauh ini belum diketahui daya saingnya baik secara keunggulan kompetitif dan komperatif walaupun secara data statistik pada Tabel 1.3 menunjukkan bahwa usahatani kopi di Kabupaten Kepulauan Meranti sejak tahun 2010-2015 mengalami peningkatan luas lahan dan juga peningkatan jumlah produksi kopi yang dihasilkan. Untuk itu perlu dilakukan penelitian mengenai daya saing kopi di Kabupaten Kepulauan Meranti yang mencakup keunggulan kompetitif dan keunggulan komparatif komoditas kopi dan 
dampak kebijakan pemerintah serta sensitivitas usahatani kopi jika terjadi perubahan kondisi input-output.

\section{METODE PENELITIAN}

\section{Tempat Penelitian}

penelitian di lakukan di Desa Kedaburapat Kecamatan Rangsang Pesisir, Desa Tanjung Samak Kecamatan Rangsang dan Desa Bina Maju Kecamatan Rangsang Barat. Dengan dasar pertimbangan ketiga Desa ini merupakan daerah yang memproduksi kopi liberika 90\% dari total produksi Kabupaten Kepulauan Meranti.

\section{Metode Penentuan Responden}

Populasi adalah seluruh petani kopi, pedagang pengumpul, Pedagang besar dan pedagang pengecer di Kabupaten Kepulauan Meranti. Pengambilan sampel dilakukan secara purposive yang didasarkan pada pertimbangan bahwa kondisi dan aktifitas usahatani yang dilakukan oleh petani di daerah penelitian relatif sama atau homogen. Pengambilan sampel dilakukan dengan metode Stratified random sampling yaitu membagi responden kedalam kelas yaitu responden untuk Desa Kedaburapat, Desa Tanjung Samak dan desa Bina Maju.

\section{Metode Pengambilan Data}

Data penelitian adalah data primer dan data sekunder. Data primer diperoleh dari wawancara kepada sejumlah petani kopi, pedagang pengumpul, Pedagang Besar, pedagang pengecer dan pengusaha yang terlibat langsung dalam kegiatan usahatani kopi dan pengembangan komoditas kopi. Data sekunder dikumpulkan dari berbagai literature, dokument hasil penelitian pada instansi pertanian, perkebunan, BPS, dan instansi terkait lainnya yang berupa hasil hasil penelitian sejenis baik komoditas ataupun alat analisis, data luas lahan kopi dan jumlah produksi kopi serta data profil wilayah Kabupaten Kepulauan Meranti dan Rencana Pembangunan Jangka Menengah (RPJM) Kabupaten Kepulauan Meranti.

\section{Metode Analisis Data}

Penelitian ini di analisis menggunakan metode PAM (Policy Analysis Matrix) Tabel 3.2 Matriks Analisis Kebijakan (PAM)

\begin{tabular}{|c|c|c|c|c|}
\hline \multirow{2}{*}{ Keterangan } & $\begin{array}{c}\text { Penerim } \\
\text { aan }\end{array}$ & $\begin{array}{c}\text { Input } \\
\text { Tradable }\end{array}$ & $\begin{array}{c}\text { Input non } \\
\text { tradable }\end{array}$ & \multirow{2}{*}{ Keuntungan } \\
& &
\end{tabular}




\begin{tabular}{|l|c|c|c|c|}
\hline Harga Privat & A & B & C & D=A-B-C \\
Harga Sosial & E & F & G & H= E-F-G \\
Dampak kebijakan & I = A-E & J=B-F & K= C-G & L= D-H = I-J-K \\
\hline
\end{tabular}

Sumber: Monke and S.R Pearson (1989)

Keterangan :

Penerimaan usahatani kopi pada harga privat $=\mathrm{A}$

Total biaya tradable usahatani kopi pada harga privat $=\mathrm{B}$

Total biaya nontradable usahatani kopi pada harga privat $=\mathrm{C}$

Tingkat keuntungan pada harga privat $=\mathrm{D}$

Penerimaan usahatani kopi pada harga sosial $=\mathrm{E}$

Total biaya tradable usahatani kopi pada harga sosial $=\mathrm{F}$

Total biaya non tradable usahatani kopi pada harga sosial $=\mathrm{g}$

Keuntungan sosial $=\mathrm{H}$

Transfer output $(\mathrm{OT})=\mathrm{I}$

Transfer input $(\mathrm{IT})=\mathrm{J}$

Transfer Factor $(\mathrm{TF})=\mathrm{K}$

Transfer bersih $(\mathrm{NT})=\mathrm{L}$

Rasio biaya private $(\mathrm{PCR})=\mathrm{C} /(\mathrm{A}-\mathrm{B})$

Rasio biaya sumberdaya domestic $(\mathrm{DRCR})=\mathrm{G} /(\mathrm{E}-\mathrm{F})$

Koefisien proteksi output nominal $(\mathrm{NPCO})=\mathrm{A} / \mathrm{E}$

Koefisien proteksi input nominal $(\mathrm{NPCI})=\mathrm{B} / \mathrm{F}$

Koefisien proteksi efektif $(\mathrm{EFC})=(\mathrm{A}-\mathrm{B}) /(\mathrm{E}-\mathrm{F})$

Koefisien keuntungan $(\mathrm{PC})=\mathrm{D} / \mathrm{H}$

Rasio subsidi untuk produsen $(\mathrm{SRP})=\mathrm{L} / \mathrm{E}$

Baris pertama dari Matrik PAM adalah perhitungan dengan harga pasar (privat), yaitu harga yang betul-betul dibayarkan petani. Baris kedua merupakan penghitungan yang didasarkan pada harga sosial (shadow price), yaitu harga yang menggambarkan nilai sosial yang sesungguhnya bagi unsur biaya maupun hasil. Danbaris ketiga merupakan perbedaan perhitungan dari harga privat dengan harga social sebagai akibat dari dampak kebijaksanaan.

\section{HASIL DAN PEMBAHASAN}

Tabel 5.2. Analisis Kebijakan Usahatani Kopi Liberika di Kabupaten Kepulauan Meranti Tahun 2015 (per Ha per Tahun)

\begin{tabular}{|l|r|r|r|r|}
\hline \multicolumn{1}{|c|}{ Uraian } & Penerimaan & \multicolumn{2}{c|}{ Biaya Input } & \multirow{2}{*}{ Keuntungan } \\
\cline { 3 - 4 } & & \multicolumn{1}{|c|}{ Tradable } & Non Tradable & \\
\hline Harga Privat & 37.332 .000 & 0 & 3.384 .750 & 33.947 .250 \\
\hline Harga Sosial & 46.116 .000 & 0 & 3.372 .800 & 42.743 .200 \\
\hline Dampak Kebijakan & $(8.784 .000)$ & 0 & 11.950 & $(8.795 .950)$ \\
\hline
\end{tabular}

Sumber : Data Primer Dianalisis, Januari 2017

Nilai penerimaan, biaya produksi dan biaya lainnya kemudian dihitungkedalam analisis finansial dan analisis ekonomi, selanjutnya dialokasikan 
ke dalam komponen tradable dan non tradable. Penerimaan usahatani di peroleh dari hasil perkalian jumlah output yang dihasilkan dengan harga jual. Untuk penerimaan privat (privat provitability) harga jual di dasarkan pada harga jual yang diterima oleh petani sebesar Rp. 34.000,00 sedangkan untuk analisis finansial menggunakan harga sosial berdasarkan harga fob (free on board) sebesar Rp. $42.000,00$.

Jumlah produksi kopi rata-rata per Ha/thn yang dihasilkan dari kegiatan usahatani kopi liberika di Kabupaten Kepulauan Meranti adalah sebesar 1,098 kg, jumlah output ini di kalikan harga privat maka di dapatkan penerimaan berdasarkan harga privat sebesar Rp. 37.332.000,00, sedangkan untuk Hasil perhitungan dari penerimaan, biaya produksi dan biaya tataniaga dapat dilihat pada Tabel 5.3

Tabel 5.3Penerimaan Usahatani Kopi Liberika di KabupatenKepulauanMeranti

\begin{tabular}{|l|l|l|l|l|l|l|}
\hline komponen & Satuan & Vol & $\begin{array}{l}\text { Harga } \\
\text { Privat }\end{array}$ & $\begin{array}{l}\text { Penerimaan } \\
\text { Privat }\end{array}$ & Harga Sosial & Penerimaan Sosial \\
\hline Produksi & $\mathrm{Kg}$ & $\begin{array}{l}1.09 \\
8\end{array}$ & 34.000 & 37.332 .000 & 42.000 & 46.116 .000 \\
\hline
\end{tabular}

Sumber : Data Primer Dianalisis, Januari 2017

Setelah perhitungan-perhitungan tersebut dilakukan, maka disusun matriks PAM yang dapat dilihat pada Tabel 5.2 dan lampiran 5. Keunggulan kompetitif suatu komoditas ditentukan oleh nilai-nilai keuntungan privat (PP/ Private Profitability) dan nilai Rasio Biaya Privat (PCR/Private cost ratio). Hasil analisis dengan metode Policy Analysis Matrix (PAM) menunjukkan bahwa usahatani kopi liberika di Kabupaten Kepulauan Meranti mempunyai keunggulan kompetitif.

Hasil analisis dengan metoda Policy Analysis Matrix (PAM) menunjukkan bahwa nilai PP untuk usahatani kopi di Kabupaten Kepulauan Meranti adalahRp. 33.947.250/ha/tahun. Ini menunjukkan bahwa kegiatan usahatani kopi menguntungkan dan memiliki keuntungan kompetitif. Indikator efisiensi finansial dari pengusahaan suatu komoditi digambarkan oleh nilai PCR. Nilai PCR untuk usahatani kopi lebih kecil dari satu 1 yaitu sebesar 0,39, artinya usahatani kopi baik untuk diusahakan karena memiliki keunggulan kompetitif. Keunggulan kompetitif suatu komoditi dapat dilihat dari bagaimana alokasi sumberdaya diarahkan untuk mencapai efisiensi finansial dalam pengusahaan komoditi 
(Indriyanti, 2007). Semakin rendah nilai PCR suatu komoditi maka akan semakin besar keunggulan kompetitif yang dimilikinya.

\section{Analisis Keunggulan Komperatif Usahatani Kopi Liberika di Kabupaten Kepulauan meranti}

Keunggulan Komperatif suatu komoditas ditentukan oleh nilai-nilai keuntungan social (SP/Social Profitability) dan nilai ratio sumber daya domestik (DRCR/Domestic Resource Cost Ratio). Hasil analisis dengan metode PAM menunjukkan bahwa nilai SP untuk usahatani kopi adalah Rp42.743.200,00/ha/tahun Ini menunjukkan bahwa usahatani kopi layak diusahakan dan memiliki keuntungan komparatif. Social Profitability (SP) adalah keuntungan yang diperoleh jika terjadi pasar persaingan sempurna, dimana tidak ada campur tangan pemerintah dan kegagalan pasar.

Sedangkan nilai DRCR usahatani kopi di Kabupaten Kepulauan Meranti adalah 0,07. Nilai tersebut menunjukkan bahwa untuk mendapatkan 1 unit nilai tambah diperlukan biaya domestik sebesar 0,07 unit pada usahatani kopi. Dalam kaitan perdagangan internasional maka nilai rasio DRCR usahatani kopi sebesar 0,07 menunjukkan tingginya keunggulan komparatif usahatani kopi di Kabupaten Kepulauan Meranti. Semakin rendah nilai koefisien DRCR berarti semakin tinggi keunggulan komparatif usahatani kopi di Kabupaten Kepulauan Meranti yang artinya usahatani kopi ini mampu bertahan walaupun tanpa bantuan pemerintah karena memiliki sumber daya domestik yang diperlukan bagi pengembangan komoditas kopi terutama didukung dengan kondisi alam di Kabupaten Kepulauan Meranti yang sesuai dengan topografi yang di butuhkan untuk pertumbuhan kopi yang baik danmenghasilkan produksi yang optimal.

Dampak Kebijakan Pemerintah Terhadap Output

Tabel 5.4 Dampak Kebijakan Pemerintah terhadap output

\begin{tabular}{|l|l|l|}
\hline \multicolumn{1}{|c|}{ Dampak Kebijakan } & \multicolumn{1}{c|}{ Simbol } & \multicolumn{1}{c|}{ Nilai } \\
\hline Output Transfer & OT & $(8.784 .000,00)$ \\
\hline Nominal Protection Coeffision on Output & NPCO & 0.80952381 \\
\hline
\end{tabular}

Sumber : Data Primer Dianalisis, Januari 2017

Nilai Output Trasfer (OT) dan Koefisien proteksi output nominal/Nominal protection coefficient on output (NPCO) pada usahatani kopi di Kabupaten Kepulauan Meranti dapat dilihat pada Tabel 5.4 dan Lampiran 5. Hasil analisis 
dengan metode PAM diketahui bahwa nilai OT pada usahatani kopi adalah negatif 8.784.000,00 artinya harga privat kopi lebih rendah dibandingkan dengan harga sosialnya. Kondisi ini menunjukkan bahwa adanya intervensi pemerintah pada output terhadap usahatani tersebut lebih menguntungkan konsumen karena konsumen membeli hargayang lebih rendah dari harga sebenarnya. Dengan kata lain terjadi pengalihan suplus dari produsen ke konsumen. Sementara petani sendiri merasakan lebih baik tidak ada intervensi dari pemerintah seperti pajak yang dibebankan kepada pedagang, kenaikan harga BBM yang berpengaruh pada biaya transfortasi karena intervensi yang dilakukan oleh pemerintah menyebabkan petani tidak dapat menerima harga private (private price) sama seperti harga sosial (shadow price) atau paling tidak mendekati harga sosial.

Dampak Kebijakan Terhadap Input

Tabel 5.5 Dampak Kebijakan Pemerintah terhadap Input

\begin{tabular}{|l|l|c|}
\hline \multicolumn{1}{|c|}{ Dampak Kebijakan } & \multicolumn{1}{|c|}{ Simbol } & Nilai \\
\hline Transfer Factor & TF & $11.950,00$ \\
\hline
\end{tabular}

Sumber : Data Primer Dianalisis, Januari 2017

Hasil analisis dengan metode PAM diketahui bahwa nilai Transfer Faktor (TF) mampu menggambarkan intervensi pemerintah terhadap input non tradable. Hasil Analisis dengan menggunakan metode PAM diketahui bahwa nilai TF Rp.11.950,00. Nilai Transfer Faktor yang bernilai positif tersebut menggambarkan bahwa harga input non tradable yang dikeluarkan pada harga finansial lebih tinggi dibandingkan dengan input non tradable pada harga sosial atau harga yang seharusnya dibayarkan. Pada pengusahaan usahatani kopi, produsen harus membayar input non tradable lebih tinggi dari yang seharusnya dibayarkan, mereka mengalami kerugian sebesar Rp. 11.950,00 per hektar per tahun. Nilai TF yang positif menunjukkan bahwa terdapat kebijakan pemerintah terhadap input domestik berupa pajak. Adanya perbedaan pada biaya non tradable finansial dan ekonomi disebabkan oleh unsure pajak. Pada analisis ekonomi pajak tidak dimasukkan kedalam perhitungan karena analisis ekonomi dilakukan dengan asumsi tanpa adanya campur tangan pemerintah.

\section{Dampak Kebijakan Pemerintah Terhadap Input-Output}

Analisis kebijakan pemerintah pada input-output merupakan gabungan antara kebijakan input dan kebijakan output. Dampak kebijakan secara 
keseluruhan baik terhadap input maupun output dapat dilihat dari Koefisien Proteksi Efektif/ Efective protection coefficient (EPC), Trasfer bersih/Net Trasfer (NT), Koefisien keuntungan/Profitability Coefficient (PC) dan Rasio Subsidi bagi Produsen/Subsidi Ratio to producer (SRP).

Tabel 5.6 Dampak Kebijakan Pemerintah terhadap Input-output

\begin{tabular}{|l|l|l|}
\hline \multicolumn{1}{|c|}{ Dampak Kebijakan } & \multicolumn{1}{|c|}{ Simbol } & \multicolumn{1}{c|}{ Nilai } \\
\hline Efective protection coefficient & EPC & 0.81 \\
\hline Net Transfer & NT & $(8.795 .950,00)$ \\
\hline Profitability Coefficient & PC & 0.79421405 \\
\hline Subsidi Ratio to Producer & SRP & -0.1073532 \\
\hline
\end{tabular}

Sumber : Data Primer Dianalisis, Januari 2017

Didalam alat analisis PAM, indikator yang mampu menjelaskan pengaruh dampak kebijakan terhadap surplus produsen adalah nilai Tranfer Bersih (NT). Nilai Transfer Bersih merupakan selisih dari nilai keuntungan privat dengan nilai keuntungan sosial. Hasil perhitungan indikator pada analisis kebijakan input output usahatani kopi di Kabupaten Kepulauan Meranti dapat dilihat pada Tabel 5.6. Koefisien proteksi/effective proctection coefficient (EPC) merupakan gabungan antara koefisien proteksi output nominal/Nominal protection coefficient on Output (NPCO) dengan koefisien proteksi Input Nominal/Nominal protection coefficient on tradable input (NPCI). EPC menggambarkan sejauh mana kebijakan pemerintah bersifat melindungi produksi domestic secara efektif. EPC merupakan rasio antara selisih penerimaan dan biaya input tradable yang dihitung pada harga aktual dengan selisih penerimaan dan biaya input tradable yang dihitung pada harga bayangan (shadow prices). Nilai EPC lebih dari satu (EPC>1) berarti kebijakan pemerintah untuk melindungi produsen domestic berjalan efektif, jika kurang dari satu (EPC <1) maka kebijakan tersebut tidak berjalan secara efektif atau menghambat produsen untuk berproduksi.

\section{Analisis Sensitivitas Terhadap Daya Saing Usahatani Kopi}

Perubahan-perubahan yang terjadi dalam pengusahaan usahatani kopi sedikit banyak akan berpengaruh pada daya saing komoditi kopi tersebut. Keterbatasan Matriks Analisis Kebijakan (PAM) yaitu analisis yang dilakukan bersifat statis (hanya berlaku pada musim bersangkutan) sehingga memerlukan simulasi untuk mengantisipasi setiap perubahan yang terjadi pada sistem ekonomi yang dinamis. Untuk menutupi keterbatasan tersebut maka dilakukanlah analisis 
sensitivitas. Analisis Sensitivitas digunakan untuk mengetahui daya saing komoditi kopi apabila terjadi perubahan-perubahan pada variabel biaya maupun variabel penerimaan.

\section{Analisis Sensitivitas Jika Terjadi Penurunan jumlah output sebesar 35\%}

Jumlah output yang dihasilkan dalam suatu usahatani sangat mempengaruhi jumlah penerimaan yang akan di terima oleh petani, karena walaupun harga produk mahal tetapi jika output yang dihasilkan sedikit tetap saja penerimaan yang di terima petani menjadi lebih sedikit bila di bandingkan jika jumlah output lebih banyak. Kondisi ini sangat mungkin terjadi jika terjadi kegagalan panen karena serangan hama dan penyakit tanaman, yang disebabkan hewan ataupun penyakit karat yang hidup di batang kopi yang menyebabkan kopi berpoduksi lebih sedikit. Penurunan jumlah output di tingkatan petani yang pernah terjadi adalah sebesar $35 \%$

Dari hasil analisis yang dilakukan di dapatkan hasil bahwa jika terjadi penurunan jumlah output sebesar 35\% maka nilai keuntungan yang diterima petani menjadi semakin kecil yaitu sebesar Rp. 22.391.250,00 Per Ha/per Th. kondisi harga privat yang diterima oleh petani.(Lampiran 9). Penurunan jumlah output sebesar 35\% ini juga mengakibatkan nilai PCR dan DRCR juga naik menjadi 0.33 dan 0.06 , walaupun tetap berada di bawah 1, yang artinya tetap mempunyai daya saing secara kompetitif dan komperatif tetapi dengan meningkatnya nilai PCR dan DRCR ini menunjukkan bahwa daya saing usahatani kopi liberika di Kabupaten Kepulauan Meranti mengalami penurunan secara kompetitif dan komperatif tetapi tetap punya daya saing.

Penurunan daya saing yang terjadi karena penurunan jumlah output sebesar 35\% ini menujukkan bahwa daya saing di pengaruhi oleh faktor agroekologi (soetriono, 2009) yaitu dari faktor internal usahatani itu sendiri yaitu jumlah output yang dihasilkan, daya saing mengalami penurunan ketika jumlah output yang dihasilkan menurun. Walaupun mengalami penurunan nilai PCR dan DRCR usahatani kopi liberika di Kabupaten Kepulauan Meranti tetap memiliki keunggulan kompetitif dan keunggulan komperatif yang artinya mempunyai kelayakan dan kemampuan untuk bersaing dengan komoditas sejenis dari tempat lain. Kasus penurunan jumlah output ini dapat dihindari dengan penggunaan 
teknologi yang ada dan pemeliharan yang intensif, dan kalaupun terjadi bisa karena faktor eksternal yang tidak bisa dikendalikan oleh manusia seperti bencana alam dan serangan hama dari wilayah lain.

\section{Analisis Sensitivitas Jika Terjadi Penurunan harga output sebesar40\%}

Penurunan harga output pada tingkat harga tertinggi yang pernah di alami petani bedasarkan analisis ternyata sangat berpengaruh terhadap keuntungan yang diterima oleh petani. Petani hanya menerima keuntungan sebesar Rp. 20.514.450,00/Ha/tahun. Nilai PCR mengalami penurunan dari0,39 menjadi 0,08 sementara nilai DRCR dari 0,07 menjadi 0,04 (Tabel 5.7 dan Lampiran 11). Nilai PCR yang menjauhi angka satu menunjukkan bahwa usahatani kopi liberika di kabupaten Kepulauan Meranti mengalami peningkatan daya saing secara kompetitif karena meningkatnya harga output.

Peningkatan harga output ini menunjukkan bahwa persoalan daya saing bukan saja disebabkan faktor internal dari kegiatan usahatani itu sendiri tapi juga di pengaruhi oleh faktor eksternal (Soetriono, 2009). Dalam hal ini kondisi perekonomian pasar kopi internasional karena seperti di ketahui bahwa harga kopi dunia ditentukan dari pasar perekonomian internasional melalui wadah international organization coffea (ICO). Pemerintah Indonesia sendiri belum mampu untuk menentukan harga sendiri. Kebijakan yang mungkin bisa dilakukan pemerintah adalah pemberian subsidi positif yang dapat meningkatkan harga yang diterima produsen sehingga bisa menjadi lebih tinggi, sehingga petani tidak mengalami kerugian karena penurunan harga jual produk.

\section{KESIMPULAN}

1. Usahatani kopi liberika di Kabupaten Kepulauan Meranti mempunyai keunggulan kompetitif yang tinggi ditandai nilai $\mathrm{PCR}<1$ yaitu sebesar 0,39.

2. Usahatani kopi liberika di Kabupaten Kepulauan Meranti mempunyai keunggulan komperatif yang ditandai dengan nilai $\mathrm{DRCR}<1$, yaitu sebesar 0,07 .

3. Berdasarkan analisis sensitivitas maka usahatani kopi liberika di Kabupaten Kepulauan Meranti masih tetap mempunyai daya saing yang tinggi walaupun mengalami perubahan kondisi input-output baik secara kompetitif dan komperatif. 
4. Jika terjadi perubahan input-output secara serentak karena perubahan kondisi perekonomian maka usahatani kopi liberika di Kabupaten Kepulauan Meranti tetap memilki keunggulan komperatif, tetapi tidak memilki keunggulan kompetitif.

\section{SARAN}

1. Perlu adanya kebijakan input-output agar dapat melindungi petani kopi sehinga petani dapat menerima harga privat yang bagus untuk meningkatkan penerimaan mereka.

2. Subsidi terhadap input tradable tetap dipertahankan agar usahatani kopi tetap mempunyai daya saing kompetitif yang baik.

\section{DAFTAR PUSTAKA}

Adisasmita, Rahardjo. 2013. Pembangunan Perdesaan :Pendekatan Partisipatif, Tipologi, Strategi, Konsep Desa Pusat Pertumbuhan. Graha Ilmu, Yogyakarta.

Ariani. 2003. Analisis Daya Saing Usaha Tani Tebu di Propinsi Jawa Timur. Pusat penelitian dan Pengembangan Sosial Ekonomi Pertanian Badan Litbang Pertanian, Departemen Pertanian, Bogor.

Badan Pusat Statistik Provinsi Riau. 2013. Pekanbaru.

Dinas Kehutanan dan Perkebunan Kabupaten Kepulauan Meranti. 2013.

Dinas Perkebunan Provinsi Riau. 2014.

Halwani, R.H. 2002. Ekonomi Internasional dan Globalisasi Ekonomi. Penerbit Ghalia Indonesia, Jakarta.

Hamidi, H. 2007. Daya Saing Tembakau Virginia di Pasar Ekspor. Pusat penelitian dan Pengembangan Sosial Ekonomi Pertanian Badan Litbang Pertanian, Departemen Pertanian. Jurnal Agroteknos, Bogor.

Indriyati, Sari. 2007. Analisis Daya Saing Buah Nenas Model Tumpang Sari dengan Karet (Kasus di Desa Sungai Medang, Kecamatan Cambai, Prabumulih dan di Desa Payaraman, Kecamatan Tanjung Batu, Ogan Ilir, Provinsi Sumatera Selatan). IPB. Bogor.

Kadariah dan C. Gray. 1978. Pengantar Evaluasi proyek. Lembaga Penerbitan Fakultas Ekonomi Universitas Indonesia, Jakarta.

Kuncoro, Mudrajat. 2009. Metode Riset untuk bisnis dan Ekonomi. Edisi 3, Jakarta.

Kurniawan, A.Y. 2008. Tesis : Analisis Daya Saing Usahatani Jagung pada Lahan Kering di Kabupaten Tanah Laut Kalimantan Selatan. IPB, Bogor. 
Malian. H, dkk. 2004. PermintaanEkspor dan Daya SaingPanili di Propinsi Sulawesi Utara.Pusat Penelitian dan Pengembangan Sosial Ekonomi Pertanian, Bogor.

Masyarakat Peduli Kopi Liberika Rangsang Meranti (MPKLRM). 2014. Buku Persyaratan Indikasi Geografis, Kopi Liberika Rangsang Meranti.

Monke, E.A. and E. S. Pearson. 1989. The Policy Analysis Matrix for Agricultural Development. Cornel University Press, London.

Najiyati Sri dan Danarti. 1995. Kopi Budidaya dan Penanganan Lepas Panen. PT Penebar Swadaya.

Nasir, M. 1989. Metode Penelitian. Ghalia Indonesia, Jakarta.

Novianti, T. 2003. Analisis Dampak Kebijakan Pemerintah Terhadap Daya Saing Komoditas Unggulan Sayuran. Tesis Program Pasca Sarjana. Institut Pertanian Bogor, Bogor.

Panggabean, Edy. 2011. Buku Pintar Kopi. PT Agro MediaPustaka, Jakarta Selatan.

Salvatore. 1997. Ekonomi Internasional. Erlangga. Jakarta.

Simanjuntak, S.B. 1992. Analisis Daya Saing dan Dampak Kebijaksanaan Pemerintah terhadap Daya Saing Perusahaan Kelapa Sawit Indonesia. Disertasi Doktor. Program Pascasarjana IPB. Bogor.

Soetriono. 2009. Strategi Peningkatan Daya Saing Agribisnis Kopi Robusta dengan Model Daya Saing Tree Five, Pusat Analisis Sosial Ekonomi dan Kebijakan Pertanian badan Penelitian dan Pengembangan Pertanian. Departemen Pertanian.

Sunandar, 2007. Daya saing dan Dampak Kebijakan Pemerintah TerhadapPengusahaan Komoditi Karet Alam di Kecamatan Cambai. http://Respository.ipb.ac.id/handle/123456789/55533IPB-Bogor

Agriculturtal University 2011. Diakses terakhir 19 Mei 2016, Bogor Indonesia.

Suryana, Achmad. 2014. Analisis Dayasaing Usahatani Jagung di Indonesia. Pusat Sosial Ekonomi dan Kebijakan Pertanian, Bogor.

Winahyu, Nastiti. 2015. Daya Saing dan Dampak Kebijakan Pemerintah terhadap Komoditas Kedelai di Kecamatan Suka luyu Kabupaten Cianjur. Institute Pertanian Bogor, Jawa Barat.

Zakaria, A.K, dkk. 2010.Analisis Daya Saing Komoditas KedelaiMenurut AgroEkosistem : Kasus di Tiga Provinsi di Indonesia. Jurnal Agro Ekonomi. 